\title{
A CLINICAL COMPARISON OF PANCURONIUM BROMIDE WITH D-TUBOCURARINE IN ADULT NIGERIAN PATIENTS
}

\author{
J.A.O. MAGBACBEOLA, M.B., CH.B.(BRIST.), F.F.A.F.C.S.I. ${ }^{\circ}$
}

Pancuronium hromide (Organon NA97) is a steroid compound non-depolarizing neuromuscular blocking agent, ${ }^{1}$ synthesized by Hewett and Savage in 1964. Following extensive pharmacological studies in animals, Buckett and Bonta ${ }^{2}$ suggested that this agent possessed properties similar to those of d-tubocurarine but with certain differences in side effects. Its potency is claimed to be about five times that of $d$-tubocurarine, weight for weight. ${ }^{1,3}$

The aim of the present study was to investigate the properties of pancuronium bromide on Nigerian adults and to compare its effects with those of d-tubocurarine under standardized conditions. Attempts were also made to investigate the effects of halothane when employed in conjunction with either of the two muscle relaxants.

\section{Method}

A total of 160 patients consisting of 81 men and 79 women selected at random and in physical status 1 or 2 (ASA) were included in the study. They were to undergo elective major upper abdominal operations. Ages ranged from 19 to 70 years, and all were free of metabolic or neuromuscular disorders. For the purposes of this study it was assumed that $0.1 \mathrm{mg}$ of pancuronium bromide was equipotent with $0.5 \mathrm{mg}$ of $\mathrm{d}$-tubocurarine.

The patients were divided into three groups on the basis of the anaesthetic agents employed, which will be described. Premedication consisted of atropine $0.6 \mathrm{mg}$ and meperidine 50 to $100 \mathrm{mg}$, given by intramuscular injection approximately 60 minutes prior to the induction of arraesthesia.

Grotup I consisted of 60 patients. Anaesthesia was induced with a small dose of thiopentone sodium ( 200 to $300 \mathrm{mg}$ ) followed by freshly dissolved suxamethonium bromide $40 \mathrm{mg}$ to facilitate tracheal intubation. Anaesthesia was maintained with $3.5 \mathrm{l} /$ minute nitrous oxide with $1.5 \mathrm{l} /$ minute oxygen in a semi-closed circle absorption system with controlled ventilation. Thirty of the patients received an initial dose of $0.1 \mathrm{mg} / \mathrm{kg}$ of pancuronium, and the remaining 30 patients received $0.5 \mathrm{mg} / \mathrm{kg}$ d-tubocurarine, after recovery from the effects of suxamethonium. Supplementary doses of either $1 \mathrm{mg}$ pancuronium or $5 \mathrm{mg}$ d-tubocurarine were given to suppress spontaneous ventilation, movement, straining of the abdominal muscles, or hiccup. No analgesic agent or halothane was administered to patients in this group.

Group $I I$ comprised 60 patients who were anaesthetized with thiopentone 250 $300 \mathrm{mg}$. Thirty patients were given d-tubocurarine and the remaining 30 pan-

-From the Department of Anaesthesia, University of Ibadan, Ibadan, Nigeria.

$$
615
$$

Canad. Anaesth. Soc. J., vol. 19, no. 6, November 1972 
curonium bromide in the doses given to patients in group I. Suxamethonium was omitted and tracheal intubation was attempted one minute after injection of the relaxants. The ease of intubation was assessed according to the classification of Bush $^{4}$ and McDowell and Clarke. ${ }^{5}$ Anaesthesia was maintained by the method employed for Group I patients.

Group III consisted of 40 patients anaesthetized by the method used for Group I patients but additional I per cent halothane was administered for 15 minutes during the operation from a Fluotects vaporiser placed outside a semi-closed circle absorption system. Twenty patients received pancuronium and 20 d-tubocurarine. The effects of the combination of 1 per cent halothane and the respective muscle relaxant on cardiovascular system and on the duration of the block were determined.

The onset of action of the relaxants was measured as the time interval until the tidal volume was reduced to 25 per cent of the initial value. A Wright respirometer placed at the expiratory side of the circle absorption system was employed for this purpose. The duration of action when no incremental dose was required was calculated as the average duration of operation provided the residual block was easily reversed by neostigmine. In patients where supplementary doses were required the length of action of the relaxant was taleen as the interval in minutes between the initial intravenous injection and that of the incremental dose.

The blood pressure and the pulse rate were monitored every five minutes using the pneumatic cuff and pulse monitor (The Cotel Keating Pulse Monitor) respectively. Side effects such as skin reactions (weals) and bronchospasm were observed. At the end of the operation the residual neuromuscular block was antagonized with intravenous atropine $1.2 \mathrm{mg}$ and neostignine 2.5 to $3.5 \mathrm{mg}$. The reversal was deemed excellent when adequate spontaneous ventilation and a protective cough reflex were restored immediately.

\section{Results}

Table I gives the details of the patients in the different groups. The mean age was 42.5 years ( +5.4 S.E.) and the mean weight was $59.8 \mathrm{Kg}$ ( \pm 2.9 S.E. ). Operation times ranged from 45 to 190 minutes with a mean of 64.3 minutes.

Onset of action. The mean time for the onset of action of pancuronium bromide was 3.1 minutes (S.E. \pm 0.8 . Fange 2.1-5.5) while the mean time for d-tubocurarine was 5.2 minutes (S.E. \pm 0.9 ; Range 4.3-8.2). Thus the onset of action of pancuronium was significantly more rapid than that of d-tubocurarine $(\mathrm{P}<0.05)$.

Duration of action. The majority of operations lasted for more than one hour and since induction of anaesthesia was started at least 20 minutes before the start of operation it was possible to assess more accurately the relative duration of action of the two relaxants ( Table II). The mean duration of action of pancuronitum was shorter than that of d-tubocurarine. This difference however was not significant. Table II also shows that patients who were given pancuronium required more incremental doses of relaxant than those who received d-tubocurarine.

Ease of Intubation. Table II also shows that 60 seconds after injection of the relaxants, tracheal intubation could be accomplished with ease in 25 per cent of 
MAGBAGBEOLA: COMPARISON OF PANCURONTUM \& D-TUBOCURARINE

TABLE I

Details of Patients in the Three Groups

\begin{tabular}{|c|c|c|c|c|c|c|}
\hline & \multirow{2}{*}{$\begin{array}{c}\text { Anaesthetic } \\
\text { Agents }\end{array}$} & \multirow{2}{*}{$\begin{array}{c}\text { No of } \\
\text { Patients }\end{array}$} & \multicolumn{2}{|c|}{ Sex } & \multirow{2}{*}{$\begin{array}{c}\text { Mean Age } \\
\text { (yr) } \\
\text { Range }\end{array}$} & \multirow{2}{*}{$\begin{array}{c}\text { Mean weight } \\
\mathrm{K}_{\mathrm{g}}\end{array}$} \\
\hline & & & Male & Female & & \\
\hline \multirow[t]{2}{*}{$\begin{array}{l}\text { Group } \\
\text { I }\end{array}$} & $\begin{array}{l}\text { Thiopentore } \\
\text { Suxamethonium } \\
\text { Panctronium }\end{array}$ & 30 & 19 & 11 & $\begin{array}{c}42 \\
(19-70)\end{array}$ & 59.5 \\
\hline & $\begin{array}{l}\text { Thiopentone } \\
\text { Suxamethonium } \\
\text { d-tubocurarine }\end{array}$ & 30 & 16 & 14 & $\begin{array}{c}45 \\
(21-65)\end{array}$ & 61.6 \\
\hline \multirow{2}{*}{$\begin{array}{l}\text { Group } \\
\text { II }\end{array}$} & Thiopentone & 30 & 14 & 16 & 46 & 58.2 \\
\hline & $\begin{array}{l}\text { Pancuronium } \\
\text { Thiopentone } \\
\text { d-tubocurarine }\end{array}$ & 30 & 12 & 18 & $\begin{array}{c}41 \\
(20-65)\end{array}$ & 63.4 \\
\hline \multirow[t]{2}{*}{$\begin{array}{l}\text { Group } \\
\text { III }\end{array}$} & $\begin{array}{l}\text { Thiopentone } \\
\text { Suxamethonium } \\
\text { Pancuronium } \\
\text { Halothane }\end{array}$ & 20 & 10 & 10 & $\begin{array}{c}40 \\
(28-58)\end{array}$ & 58.5 \\
\hline & $\begin{array}{l}\text { Thiopentone } \\
\text { Suxamethonium } \\
\text { d-tubocurarine } \\
\text { Halothane }\end{array}$ & 20 & 10 & 10 & $\begin{array}{c}43 \\
(26-62)\end{array}$ & 60.5 \\
\hline Total & & 160 & 81 & 79 & & \\
\hline
\end{tabular}

patients given pancuronium as against 5 per cent of patients given d-tubocurarine. After three minutes, tracheal intubation could be done without difficulty in the majority of patients given pancuronium. A longer period of up to five minutes or more was required for patients who had received d-tubocurarine.

Cardiovascular changes. In this series the cardiovascular effects of the relaxants were mainly studied prior to the surgical stimulus. There was no change in the systolic blood pressure in 24 per cent of patients given pancuronium as against only 10 per cent in the d-tubocurarine group (Table III). This table also shows the distribution of the changes in systolic blood pressure. The systolic pressure appeared to be fairly stable or slightly elevated in the patients given pancuronium while there was a tendency towards transient hypotension in the patients given d-tubocurarine. Table III also shows that supplementation with 1 per cent Halothano resulted in a greater fall in systolic blood pressure in patients given d-tubocurarine than in the pancuronium sub-group. The maximum fall in systolic pressure of $50 \mathrm{~mm} \mathrm{Hg}$ was observed in 10 per cent of patients given d-tubocurarine.

The pulse rate remained steady in 60 per cent of patients who received pancuronium bromide and 55 per cent in the d-tubocurarine group (Table IV). A decrease of between 11 and 20 beats per minute was observed in 5 per cent of patients given d-tubocurarine while 40 per cent of patients of the two sub-groups had a fall of less than 10 beats per minute.

Although the number of patients in group III was small, it would appear that the addition of halothane increased the duration of action of d-tubocurarine more than that of pancuronium, but only slightly so (Table II).

Other side effects. Twenty-five per cent of the patients given d-tubocurarine developed weals, mainly in the arm in which the injection was given and on the 
TABLE III

Percentage Incrofence of Changes in Systolic Bloon Pressure Following Induction of ANaesthesia and INjection of Miscle Relaxants

\begin{tabular}{|c|c|c|c|}
\hline \multirow[b]{2}{*}{$\begin{array}{c}\text { Change in Systolic } \\
\text { Blood Pressure }\end{array}$} & \multicolumn{2}{|c|}{$\begin{array}{l}\text { Percentage Incidence of } \\
\text { Changes in Systolic Presstre - } \\
\text { Groups I and IJ }\end{array}$} & $\begin{array}{c}\text { Percentage Changes } \\
\text { In Systolic Blood } \\
\text { Pressure - Growp 1II }\end{array}$ \\
\hline & $\begin{array}{l}\text { Patients given } \\
\text { Pancuronium in } \\
\text { Grougs I \& II } \\
(60)^{*}\end{array}$ & $\begin{array}{l}\text { Patients givent } \\
\text { d- } 1 \text { ubocurarine } \\
\text { in Groups } \\
\text { I \& II }(60)^{*}\end{array}$ & $\begin{array}{l}\text { Pancuronium d-tubocurarine } \\
(20)^{*}\end{array}$ \\
\hline
\end{tabular}

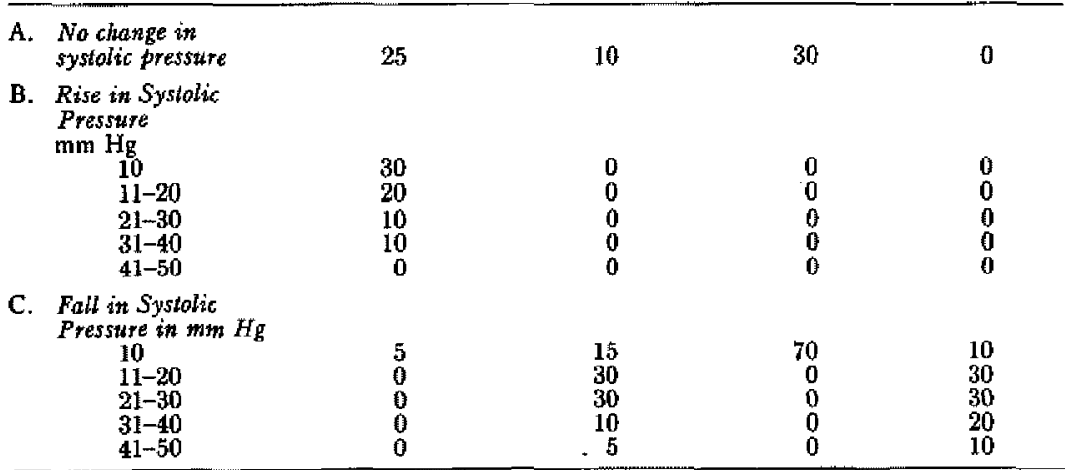

- Indicates total number of patients.

trunk. These observations were made before transfusion, to exclude any reaction caused by blood. None of the patients given pancuronium showed any skin reaction.

Bronchospasm was not noticed in any of the patients. The reversal of neuromuscular block was smooth with immediate return of spontaneous ventilation in all groups. The addition of 1 per cent Halothane for 15 minutes did not seem to affect reversal.

\section{Discussion}

This study clearly confirmed earlier reports that pancuronium bromide is a potent non-depolarizing neuromuscular blocking agent, about five times as potent as d-tubocurarine." Its onset of action as estimated by depression of respiration was significantly more rapid than that of d-tubocurarine. This is in agreement with Baird and Reid ${ }^{1}$ and McDowell and Clarke. ${ }^{5}$ The duration of action was similar to that of d-tubocurarine. There was no evidence that the duration of action of pancurorium was increased by addition of 1 per cent halothane while it appeared that the duration of action of d-tubocurarine was slightly increased by halothane.

The study further confirmed that the rapid onset of action of pancuronium over tubocuratine enabled tracheal intubation to be performed more easily one minute after injection but the conditions provided for intubation were not as good as with stuxamethonium bromide. There was a slight cough as the tube passed through the cords, but more exaggerated muscular movements were often observed in the 
TABLE IV

Percentage Incidence of Changes in the Pulse Rate

\begin{tabular}{|c|c|c|c|c|}
\hline \multirow[b]{2}{*}{ Change in pulse rate } & \multicolumn{2}{|c|}{$\begin{array}{c}\text { Percentage incidence of } \\
\text { changes in pulse rate - Groups } \\
\text { I and II }\end{array}$} & \multicolumn{2}{|c|}{$\begin{array}{c}\text { Percentage incidence } \\
\text { of changes in pulse } \\
\text { rate - Group III }\end{array}$} \\
\hline & $\begin{array}{c}\text { Patients given } \\
\text { Pancuronium } \\
(60)^{*}\end{array}$ & $\begin{array}{l}\text { Patients given } \\
\text { d-tubocurarine } \\
(60)^{*}\end{array}$ & $\begin{array}{c}\text { Pancuronilem } \\
(20)^{*}\end{array}$ & $\underset{(20)^{*}}{\mathrm{~d} \text { - tubocurarine }}$ \\
\hline A. No change & 50 & 60 & 60 & 55 \\
\hline $\begin{array}{r}\text { B. Increase in } \\
10 \\
11-20 \\
21-30\end{array}$ & $\begin{array}{r}30 \\
10 \\
0\end{array}$ & $\begin{array}{r}20 \\
10 \\
0\end{array}$ & $\begin{array}{l}0 \\
0 \\
0\end{array}$ & $\begin{array}{l}0 \\
0 \\
0\end{array}$ \\
\hline $\begin{array}{r}\text { C. Decrease } \\
10 \\
11-20 \\
21-30\end{array}$ & $\begin{array}{r}10 \\
0 \\
0\end{array}$ & $\begin{array}{r}10 \\
0 \\
0\end{array}$ & $\begin{array}{r}40 \\
0 \\
0\end{array}$ & $\begin{array}{r}40 \\
5 \\
0\end{array}$ \\
\hline
\end{tabular}

*Indicates total number of patients.

patients given tubocurarine. Three minutes after injection of pancuronium, however, intubation could be done easily in 95 per cent of the patients as compared with 45 per cent of patients given d-tubocurarine. In the light of the experience gained from this study, suxamethonium would still be recommended for rapid or "crash" intubation and this could be followed by either pancuronium or d-tubocurine.

In the present study, hypotension following $d$-tubocurarine injection was clearly demonstrated in 90 per cent of patients and hypotension was further increased by the addition of 1 per cent halothane (Table III). The hypotensive effects of $d$ tubocurarine have been adequately documented ${ }^{7, s}$ although no single report has emerged from this part of the world. It would therefore appear that our patients do not react differently from those reported elsewhere. Pancuronium on the other hand, has been shown to have no effect on the blood pressure. ${ }^{1}$ This conclusion has been confirmed in this study where most of the patients had some rise in systolic blood pressure. This rise in the systolic blood pressure could be ascribed partly to the effect of pancuronium and, to a minor degree, to the stimulation caused by laryngoscopy and tracheal intubation. The hypotensive effect of the combination of halothane and pancuronium was very minimal when compared with halothane and d-tubocurarine (Table III). Neither pancuronium nor d-tubocurarine appear to have any marked effect on the pulse rate even when employed with halothane (Table IV). In view of the absence of any circulatory disturbance following the administration of pancuronium, it would appear to be a relaxant of choice for patients with tendency to hypotension such as patients under controlled ventilation, those suffering from tetanus hypovolaemia, and toxic patients.

The absence of skin reactions following the injection of pancuronium also confirmed earlier reports of the absence of histamine release. ${ }^{1.5}$ However, only 25 per cent of the patients who received d-tubocurarine developed skin reactions. This figure was lower than the 65 per cent and 50 per cent reported by McDowell \& 
Clarke. ${ }^{5}$ None of the patients in the present study developed bronchospasm. It must also be stressed that none of them had any history of asthmatic attacks.

Two conclusions could therefore be drawn from these series:- firstly, the results have confirmed earlier reports ${ }^{1,8,9}$ and, secondly, Nigerian patients react to these muscle relaxants in a manner similar to the other races already reported. Racial or environmental factors do not appear to influence the effects of these drugs.

\section{SUMMARY}

The effects of pancuronium bromide and d-tubocurarine were investigated on 160 Nigerian patients in the dose of $0.1 \mathrm{mg} / \mathrm{kg}$ body weight respectively. The onset of action of pancuronium bromide was more rapid than that of d-tubocurarine while the duration of action of the two drugs was similar. The blood pressure and pulse rate were maintained even when halothane was employed with pancuronium. d-tubocurarine on the other hand caused hypotension which was more severe in the presence of halothane. The rapid onset of action of pancuronium bromide made intubation 60 seconds after injection easier. No skin reaction was observed with pancuronium bromide.

\section{RÉsumé}

Nous avons étudié l'action du bromure de pancuronium et de la d-tubocurarine chez 60 malades nigériens dont la dose/poids variait entre $0.1 \mathrm{mg} / \mathrm{kg}$ et $0.5 \mathrm{mg} / \mathrm{kg}$ respectivement.

Le début de l'action du bromure de pancuronium est plus précoce que celui de la d-tubocurarine, mais leur durée d'action est semblable.

La pression et le pouls se sont maintenus même au cours du l'administration de l'halothane.

La d-tubocurarine a provoqué de l'hypertension qui s'est aggravée en présence de l'halothane.

Le début rapide d'action du bromure de pancuronium a facilité l'intubation 60 secondes après l'injection.

Nous n'avons observé aucune réaction cutanée avec l'usage du bromure de pancuronium.

\section{REFERENCES}

1 BAIRD, W.L.M. \& REID, A.M. The neuromuscular blocking properties of a new steroid compound, pancuronium bronide. A pilot study in man. Brit. J. Anaesth. 39 : 775-780 (1967).

2. Bucket, W.R. \& BONTA, I.L. Pharmacological studies with NA97(2,16-dipiperidine-5androstane-3,-1-diol diacetate dimenthobromide). Fed. Proc. 25: 718 (1966).

3. Sellick, B.A. Pancuronium bromide: clinical experience of a new muscle relaxant. Proc. Fourth World Congress of Anaesthesiologists p. 1144, London, Amsterdam, Excerpta Medica ( I970).

4. Bush, G.H. Clinical experiences with diallyl-nortoxiferine in children. Brit. J. Anaesth. 36: 784 (1964).

5. MCDowELL, S.A \& CLAfKe, R.S.J. A clinical comparison of pancuronium with d-tubocurarine. Anaesthesia. 24: 581 (1969). 
6. Bucketr, W.R., Majonibanks, C.E.B., Marwick, F.A., \& Morton, M.B. The pharmacology of pancuronium bromide (Org. NA97), a new potent steroidal neluromuscular blocking agent. Brit. J. Pharmac. Chemother. 32: 67t.

7. Gray, T.C. \& Halton, J. A milestone in anaesthesia? (d-tubocurarine chloride). Proc. $\mathbf{R}$ Soc. Med. 39,400 (1946).

8. ThOMAS, E.T. The effect of d-tubocurarine chloride on the blood-pressure of anaesthetised patients. Lancet. ii, 772 ( 1957 ).

9. BAIro, W.L.M. Some clinical experience with a new neuromuscular blocking drug-pancuronium bromide (Pavulon NA97). I.J. Med. Sc. 1.559 (1968). 